\title{
EVALUATION OF VIENNA'S WORLD ECONOMIC POSITION BASED ON GLOBAL AND WORLD CITY RANKINGS
}

\author{
Andrea USZKAI ${ }^{\mathrm{a}}$ \\ ${ }^{a}$ Junior research fellow, PhD Student. Hungarian Academy of Sciences Centre for Economic and \\ Regional Studies Institute for Regional Studies, Széchenyi István University Doctoral School of \\ Regional- and Economic Sciences. auszkai@rkk.hu
}

Cite this article: Uszkai, A. (2016). Evaluation of Vienna's World Economic Position Based on Global and World City Rankings. Deturope, 8, 3: 72-87

\begin{abstract}
Metropolitan areas play a dominant role in today's economic, social and environmental processes; therefore the scientific interest has also increased related to the global and world cities. They can be considered as key players of the world economy and a very complex competition takes place among them, which crosses the national state borders. Every city tries to reach the most favorable position and this rivalry has helped the birth of several city rankings. This paper has two important aims. Firstly, it explains the term of the world and global city based on the international literature and it is also looking for the answer, whether the Austrian capital belongs to which category. Secondly, it examines the position of Vienna in the different world and global city rankings.
\end{abstract}

Keywords: global city, world city, Vienna, ranking

\section{INTRODUCTION}

The last few decades have seen the world becoming more urbanised (Giap-Thye-Aw, 2014). In the year of 2014,54 percent of the world's population lived in urban areas, which may increase to 66 per cent by 2050 according to the projection of United Nations Department of Economic and Social Affairs. The importance of national economies is (relatively) decreasing and the economic role of regions and cities seems to grow (Lengyel, 2009). They are facing strong competition for investors, tourists, qualified labour or international events over the last decades (Begg, 1999) and many economic, global players need help to compare the cities from different point of view. So, the comparison of cities can support investors in their choice of location and it can be an important guide for the cities to judge their strengths and weaknesses, moreover to define their goals and strategies for future development and better positioning in the urban system (Giffinger-Haindl, 2009). Therefore, hundreds of city indexes and rankings proclaim which cities are the most global, with the most powerful economies, have the greatest universities, the richest cultures. Some of them are comprehensive, trying to 
rate cities as a whole; others specialize, focusing on a city's global financial position, its real estate values or the quality of life (Leff-Petersen, 2015).

The main objective of this paper is to collect the most common global and world city rankings and examine, where the Austrian capital is positioned yearly in them and answer the following question: can we consider Vienna as a real world or global city, and if so, what kind of economic, social, environmental or other factors are able to strengthen its position at global scale? Based on this investigation, the global position of Vienna can be described. The performance of the city in several rankings will present, which factors make strong Vienna in the global space and which are the most critical from the point of view of its competiveness. We are going to see those elements which should be strengthened in order to be more competitive among similar cities. The reviewed time horizon of several city rankings depends on the publicity and availability of data.

\section{Conceptual framework}

Large and significant cities have fascinated social scientists and this is indicated by the range of terms used to describe them: imperial cities, primate cities, great industrial cities, millionaire cities, world cities, global capitalist cities, international financial centres, megacities and global cities are all well-known designations. This variety in terminology reflects both the diversity in the nature of cities and differences of approach to the study of cities. (Beaverstock-Smith-Taylor, 1999). The term "world city" was firstly introduced by the regional planner Patrick Geddes in his 1915 book "Cities in Evolution, but his comments on world cities were mostly forgotten, however, in part because Geddes became so famous for his work on regional planning (Pearce-Wyly, 2006). Half a century later, Peter Hall (1966) defined world cities as follows: "They are centres of political power, both national and international, and of the organizations related to government; centres of national and international trade and all kinds of economic activity, acting as entrepots for their countries and sometimes for neighbouring countries also" (Hall 1966). Hall's book titled "The World Cities" analysed the attributes (politics, trade, communication facilities, finance, culture, technology, and higher education) of cities at the top of the world urban hierarchy (London, Paris, Randstad-Holland, Rhine-Ruhr, Moscow, New York, and Tokyo) (Pearce-Wyly, 2006). Manuel Castells (1989) described a new urban phenomenon: the informational city. The key issues within his definition are the new communication technologies and 
infrastructure, including information technology, telecommunications, air transportation, and the accordingly necessitated infrastructure. Furthermore, he takes financial and economic performance into consideration. The informational city is to be seen as embedded in a global system of networked information flows. Within those networks, the cities are forming a hierarchy, representing nodes and hubs according to their capacities for information exchange and their interactive and innovative performance (Castells, 1989). This approach was taken up by John Friedmann in his essay "The World City Hypothesis" (Pearce-Wyly, 2006). According to Friedman and Wolff, world cities are characterized by the "predominance of financial and service sectors in the economy". They are "closely interconnected with each other through communications and finance and these regions constitute a worldwide system of control over market expansion" (Friedmann-Wolff 1982). The World Bank has classified world cities and identified two main categories: core countries and semi-peripheral countries. Both of them contain primary and secondary cities (Friedmann, 1986). The examined capital in this paper, Vienna is defined as a secondary city in a core country (Tab. 1).

Table 1 The World City Hierarchy

\begin{tabular}{|l|l|l|l|}
\hline \multicolumn{2}{|c|}{ Core Countries } & \multicolumn{1}{c|}{ Semi-peripheral Countries } \\
\hline \multicolumn{1}{|c|}{ Primary } & \multicolumn{1}{|c|}{ Secondary } & \multicolumn{1}{c|}{ Primary } & \multicolumn{1}{c|}{ Secondary } \\
\hline London & Brussels & São Paulo & Johannesburg \\
Paris & Milan & Singapore & Buenos Aires \\
Rotterdam & Vienna & & Rio de Janeiro \\
Frankfurt & Madrid & & Caracas \\
Zurich & Toronto & & Mexico City \\
New York & Miami & & Hong Kong \\
Chicago & Houston & & Taipei \\
Los Angeles & San Francisco & & Manila \\
Tokyo & Sydney & & Bangkok \\
& & & Seoul \\
\hline
\end{tabular}

Source: Edited by author based on Friedmann (1986)

The sociologist, Saskia Sassen coined the other relevant term, the "global city." The global network of cities, she argued, is less about competition than a division of functions; some cities are hubs for finance, others for manufacturing, and so on, but all are important (LeffPetersen 2015). Sassen defined global cities as, "cities that are strategic sites in the global economy because of their concentration of command functions and high-level producer service firms oriented to world markets; more generally cities with high levels of internationalisation in their economy and in their broader social structure." (Sassen 1994:154) Sassen Sassen's work (1991) titled „The Global City New York, London, Tokyo” analysed, 
among other factors in these cities in terms of the growth of the high-paying professional jobs and low-paying lower-order clerical work, as well as the growth in part-time and temporary employment (Pearce-Wyly, 2006). But, Vienna was not mentioned among Sassen's global cities. The Austrian capital in wider context can be considered a centre of a cross-border urban region called "Centrope", which involve four countries (Hardi, 2010). In recent years, many case studies have dealt with the questions of "global city" status of individual cities or city systems and have helped to bring light to the debate of global city research. In particular, studies concerning the role of service sectors (Bourdeau-Lepage 2007), local firm networks (Rossi et al. 2007) or the role of cities as gateways (Grosfoguel 1995, Parnreiter 2002) have led to a deeper understanding of the global city network and its global-local tensions. The expansion of a world city database and a great number of case studies based on alternative data sources helped to bridge the gap between the global city theory and empirical research (Musil, 2009). The current paper tries to contribute the defining of Vienna's world economic position based on global/world city rankings.

\section{RESULTS: VIENNA'S POSITION IN WORLD AND GLOBAL CITY RANKINGS}

Firstly, A.T. Kearney's Global Cities Index (GCI) will be overviewed, which examines a comprehensive list of 84 cities on every continent across 26 metrics in five dimensions: business activity (30\%), human capital (30\%), information exchange (15\%), cultural experience (15\%), and political engagement (10\%). As in previous years, in 2014, New York and London lead the ranking, followed by Paris, Tokyo, and Hong Kong. Among the top 20 cities, seven are in the Asia Pacific region (Tokyo, Hong Kong, Beijing, Singapore, Seoul, Sydney, and Shanghai), seven are in Europe (London, Paris, Brussels, Madrid, Vienna, Moscow, and Berlin), and six are in the Americas (New York, Los Angeles, Chicago, Washington, Toronto, and Buenos Aires) (A.T. Kearney, 2015). According to this index, Vienna stand on the $18^{\text {th }}$ place in the year of 2008 and 2010, after that its position has improved and reached the $13^{\text {th }}$ place in 2012, which has decreased to the $16^{\text {th }}$ in 2014 (Fig. 1). 
Figure 1 A.T. Kearney's Global Cities Index (GCI) (2008-2014) (Cities before Vienna)

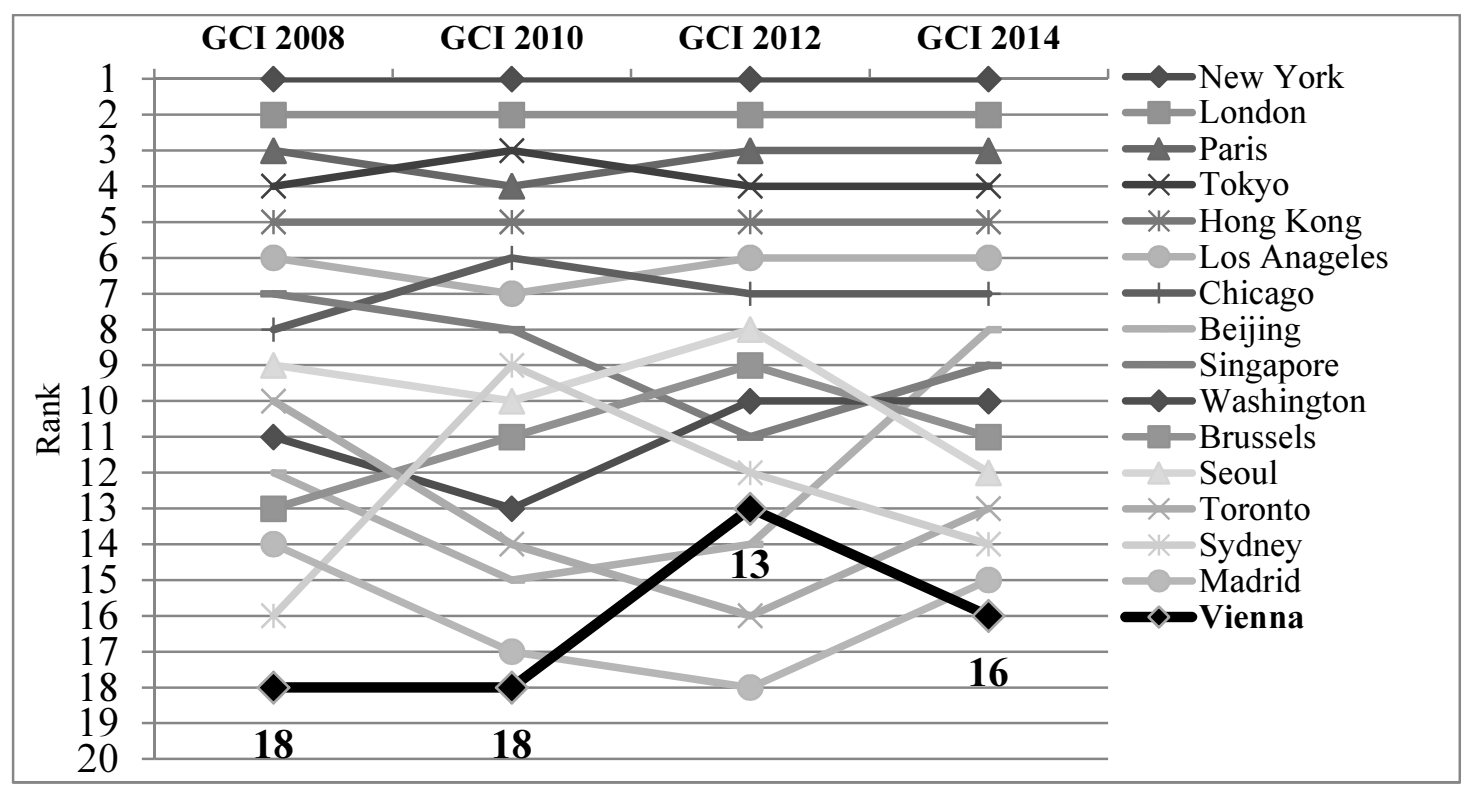

Source: Edited by author based on A.T. Kearney, 2015

Next analysed city index is the "Innovation Cities Global Index", which is the world's leading classification and top ranking of cities potential as innovation economies. Established in 2007, with 22 cities released, which was expanded to 256 cities in 2009, and to 500 cities in 2015. All cities in the index are classified for global innovation based on their potential for innovation performance across 31 segments of their city economy. Every city is analysed with 162 city indicators according to 3 factors: cultural assets of a city from arts to sports industries (1); human infrastructure from mobility to start-ups, health, finance and more (2) and networked markets, the power of a city in a networked world (3) (2thinknow Global Innovation Agency, 2016). Next table presents the results of Innovation Cities Global Index related to the TOP 10 cities between 2007 and 2015. The years of 2012 and 2013 form only one category, because the index was published for these two years jointly. During the whole period, Vienna was positioned among the first 6 cities, but its position has decreased between 2007 and 2011 year by year from the first to the fifth place. After that, the Austrian capital reached the $3^{\text {th }}$ place in 2012-2013, the $6^{\text {th }}$ place in 2014 and again the excellent $3^{\text {th }}$ place in the last year behind London and San Francisco-San Jose (Tab. 2). 
Table 2 Innovation Cities Global Index - Top 10 (2007-2015)

\begin{tabular}{|c|c|c|c|c|c|c|c|c|}
\hline & 2007 & 2008 & 2009 & 2010 & 2011 & 2012-2013 & 2014 & 2015 \\
\hline 1 & Vienna & Vienna & Boston & Boston & Boston & Boston & $\begin{array}{c}\text { San } \\
\text { Francisco - } \\
\text { San Jose }\end{array}$ & London \\
\hline 2 & Boston & Boston & Vienna & Paris & $\begin{array}{c}\text { San } \\
\text { Francisco } \\
\text { Bay Area }\end{array}$ & New York & New York & $\begin{array}{c}\text { San } \\
\text { Francisco - } \\
\text { San Jose }\end{array}$ \\
\hline 3 & Paris & Paris & Amsterdam & Amsterdam & Paris & Vienna & London & Vienna \\
\hline 4 & New York & New York & Paris & Vienna & New York & $\begin{array}{c}\text { San } \\
\text { Francisco } \\
\text { Bay Area }\end{array}$ & Boston & Boston \\
\hline 5 & Leipzig & Leipzig & $\begin{array}{c}\text { San } \\
\text { Francisco }\end{array}$ & New York & Vienna & Paris & Paris & Seoul \\
\hline 6 & Prague & Prague & London & Frankfurt & Amsterdam & Munich & Vienna & New York \\
\hline 7 & Rome & Rome & Hamburg & $\begin{array}{c}\text { San } \\
\text { Francisco }\end{array}$ & Munich & London & Munich & Amsterdam \\
\hline 8 & Melbourne & Melbourne & New York & Copenhagen & Lyon & Copenhagen & Amsterdam & Singapore \\
\hline 9 & $\begin{array}{c}\text { San } \\
\text { Francisco } \\
\& \text { Silicon } \\
\text { Valley }\end{array}$ & Berlin & Tokyo & Lyon & Copenhagen & Amsterdam & Copenhagen & Paris \\
\hline 10 & Berlin & $\begin{array}{c}\text { San } \\
\text { Francisco }\end{array}$ & Lyon & Hamburg & Toronto & Seattle & Seattle & Tokyo \\
\hline
\end{tabular}

Source: Edited by author based on 2thinknow 2016

Another approach of city comparisons is the "Smart City" rankings. The Smart City concept may be one of possible development paths of world or global cities, paying more attention on the sustainability of several infrastructure systems, environmental factors and so on. In the last two decades, the concept of "smart city" has become more and more popular in the scientific literature and international policies (Albino-Berardi-Dangelico 2015). Smart Cities have been characterised and defined by a number of factors including sustainability, economic development and a high quality of life. Enhancing these factors can be achieved through infrastructure (physical capital), human capital, social capital and/or ICT infrastructure (Foley, 2013). In the first international "Smart Cities" ranking, which was published in the online magazine "Co.Exist" in January 2012, Vienna in comparison with other international metropolises is ranked on the first place worldwide (Cohen, 2012). In the 2014 ranking of the top 10 smartest European Cities Vienna improved its rank by one place compared to 2013 and on European level reached third place behind Copenhagen and Amsterdam (wien.gv.at, 2014). Vienna - recognizing the importance of smart city approach has created the Smart City Wien Framework Strategy (2014), which focuses on the intention of preserving and further evolving the city as a liveable, socially inclusive and dynamic space for future generations. The Viennese smart city approach is based on sparing resource use in order to massively reduce $\mathrm{CO} 2$ emissions and dependencies in connection with scarce and finite resources. At the same time, Smart City Wien means to uphold and further increase 
Vienna's high quality of living and social participation. It stands for change based on innovation, active organisation and, where necessary, the development of new forms of public and private service delivery. The present Smart City Wien framework strategy is directed at all target groups of the city: Vienna's citizens, enterprises, non-profit institutions and the public sector (Smart City Wien Framework Strategy 2014).

Next overviewed index, "Cities in Motion Index (CIMI)" (calculated by IESE Business School University of Navarra Centre for Globalization and Strategy) seeks to evaluate cities considering 10 key dimensions: Governance, Urban Planning, Public Management, Technology, Environment, International Outreach, Social Cohesion, Mobility and Transport, Human Capital and Economy. In 2015, to calculate the CIMI, 148 cities were analysed (IESE, 2015). Vienna ranked at the $6^{\text {th }}$ place in 2013 and 2014, which shows an improvement compared to the year of 2012 ( $9^{\text {th }}$ place). London, New York, Seoul, Paris, Amsterdam mean the TOP 5 cities according to this index in the last year (Fig. 2).

Figure 2 IESE - Cities in Motion Index (2012-2014) (Cities before Vienna)

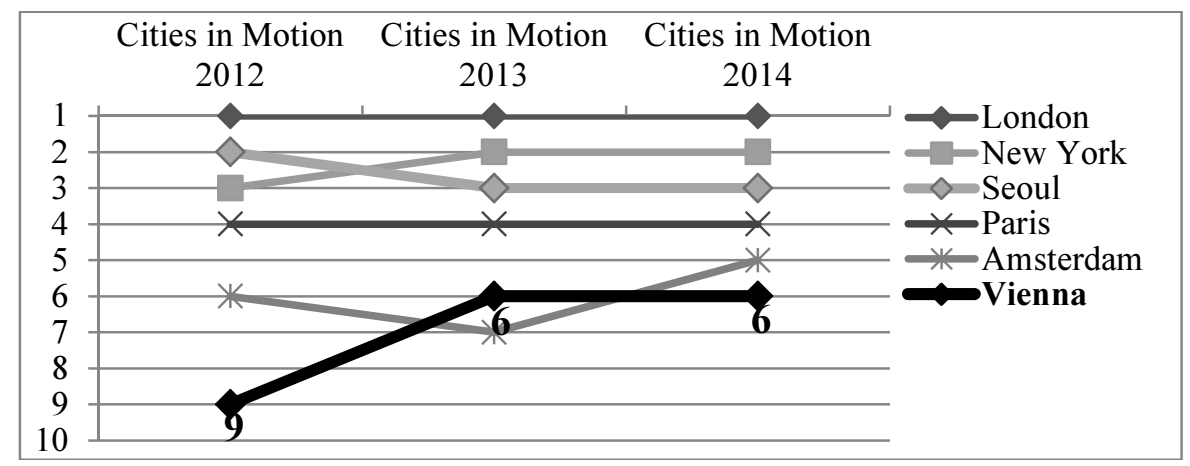

Source: Edited by author based on IESE 2015

What is more interesting: the ranks of Vienna in the several dimensions of the index. The Austrian capital achieved very good placings in the dimensions of "Mobility and Transportation" (2.); "Environment" (6.); "International Outreach" (8.) and "Urban Planning" (9.), but the city lags in the economic, technological and social factors, such as "Public Management" (27.); "Governance" (32.); "Economy" (39.); "Technology" (40.); "Social Cohesion" (55) and "Human Capital" (60). These ranks give a picture about strengths and weaknesses of Vienna in international city comparison (Fig. 3). 
Figure 3 Vienna's ranks in dimensions of Cities in Motion Index in 2014

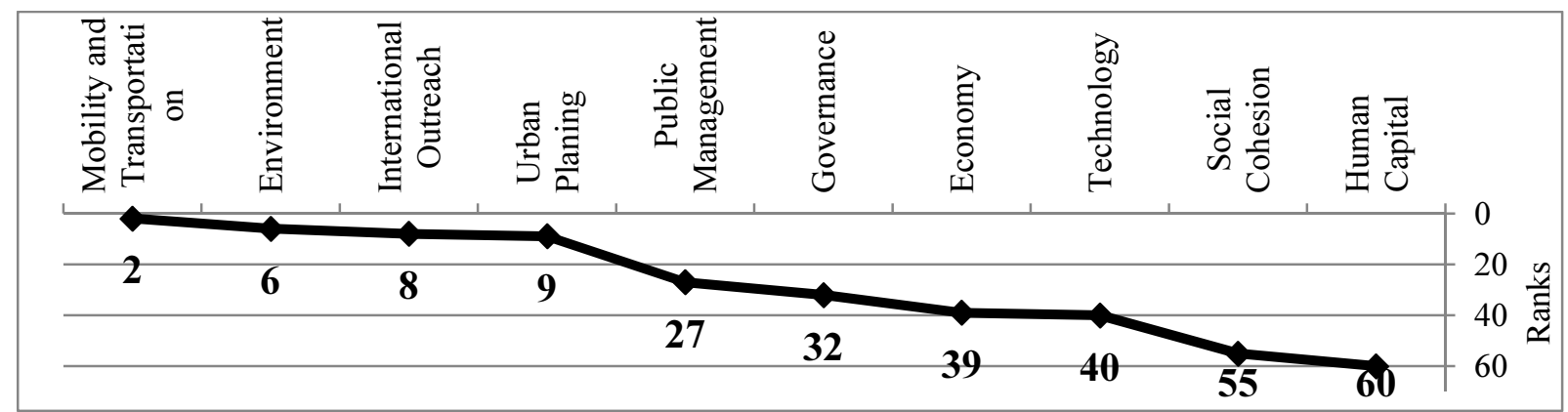

Source: Edited by author based on IESE 2015

Continuing the investigation, the next index is the "Global Power City Index" 2015 (GPCI-2015), which evaluates the comprehensive power of 40 of the world's leading cities according to six main functions (Economy, Research and Development, Cultural Interaction, Liveability, Environment and Accessibility). Additionally, the same cities were examined from the viewpoints of four global actors (Manager, Researcher, Artist and Visitor) and one local actor (Resident). The Mori Memorial Foundation's Institute for Urban Strategies first released its GPCI in 2008 and has continued to update its rankings every year based on new research. The GPCI is utilized by numerous administrative, professional, and academic organizations worldwide. Moreover, the Institute has actively engaged in dialogue with leading city experts and exchanged ideas on cities and competitiveness (Institute for Urban Strategies The Mori Memorial Foundation, 2015). In 2015, like last years, London, New York, Paris and Tokyo took the top four spots, in that order (Rubia, 2015). Vienna reached the $9^{\text {th }}$ rank, like in 2012 and 2014 (Fig 4).

In the economy category including gross domestic product, wage level, total employment, corporate tax rate and total market value of shares on stock exchanges, among others, Tokyo topped the list. In terms of research and development, New York is a clear powerhouse followed by Tokyo, London, Los Angeles and Paris. For liveability, Paris emerged as the winner, followed by Berlin, Vancouver, Vienna and Barcelona, while Geneva emerged as the winner in terms of environment, followed by Frankfurt, Stockholm, Zurich and Vienna. In terms of accessibility, Paris earned the highest score, followed by London, Amsterdam, Singapore and Hong Kong. For cultural interaction, cities like New York (ranked second), Paris (third), Singapore (fourth) and Tokyo (fifth) also earned higher scores compared to most global cities (Maceda, 2015). 
Figure 4 Global Power City Index összesített rangsora (2008-2015) (TOP 10; 2015)

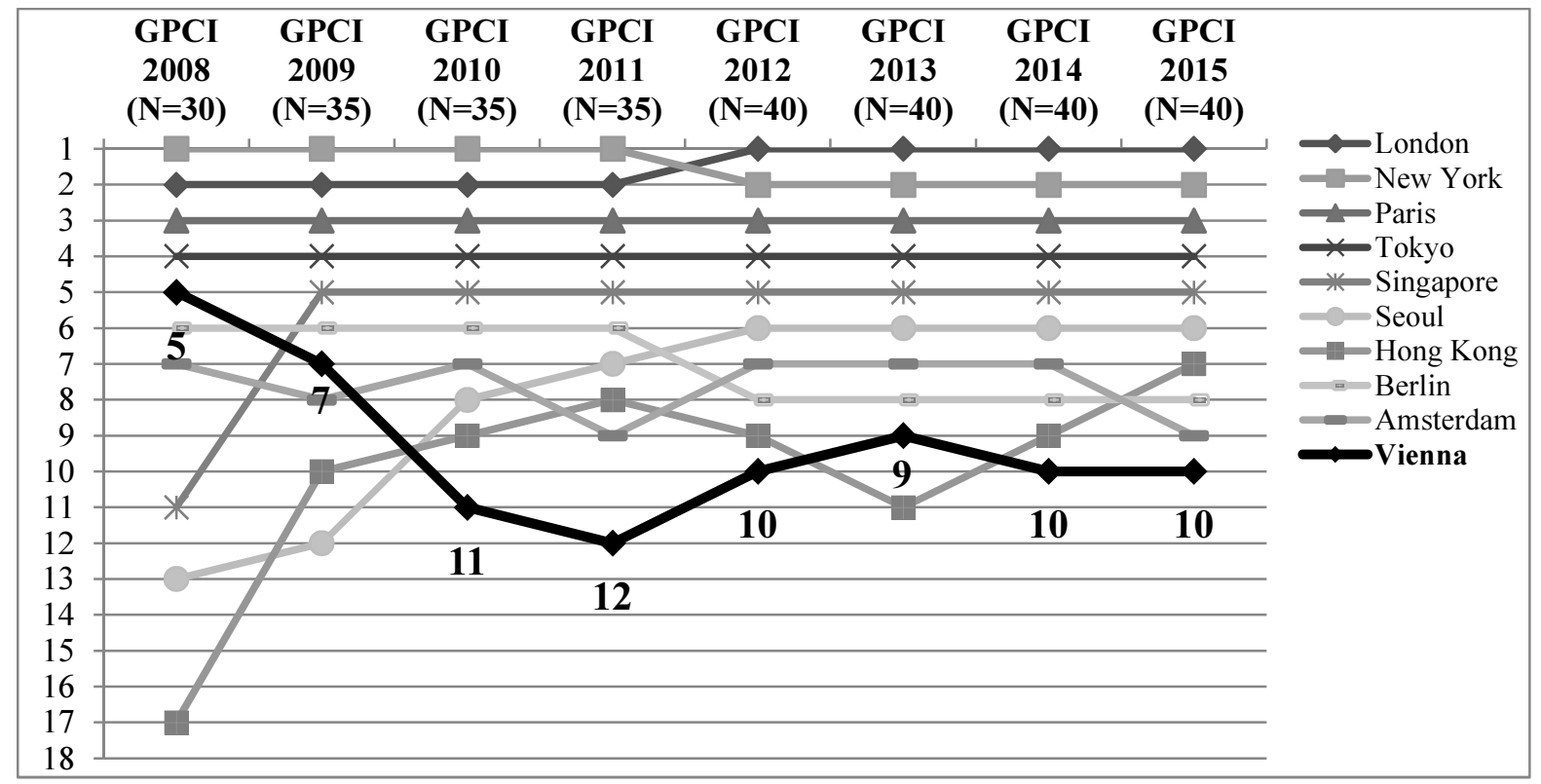

Source: Edited by author based on Institute for Urban Strategies The Mori Memorial Foundation Global Power City Index 2015

Let's take a closer look at the several dimensions of the Global Power City Index in the case of Vienna. According to the actor- and function-specific ranks, Vienna's position is outstanding in the "Liveability" (4.); "Environment" (5.); and "Cultural interaction" (9.) functions. Regarding these factors, Vienna is a leading global city. Besides this, the most important target groups of the city are "Artist" (5.); "Residents" (7.); and "Visitor" (12.). Both of rankings (actor-specific and function-specific) present excellently the strengths and weaknesses of the city in global competition (Fig. 5).

Figure 5 Global Power City Index 2015 - Vienna's position in function- and actor-specific factors

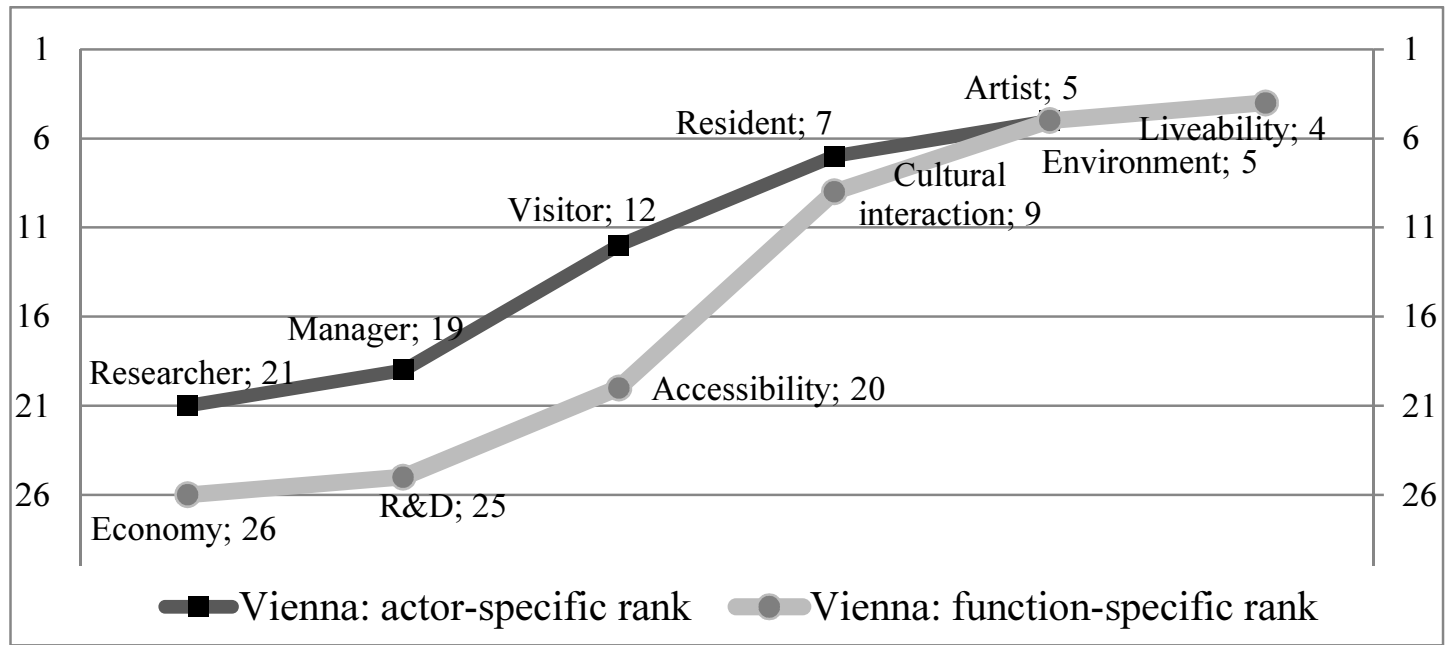

Source: Edited by author based on Institute for Urban Strategies The Mori Memorial Foundation Global Power City Index 2015 
"Liveability" is one key characteristic of cities that enable them to attract a disproportionate amount of the globally-mobile resources that are recognised to make positive contributions to economic growth, economic resilience, global political influence, world agenda-setting power, socio-cultural innovation, and international lifestyle impact (GiapThye-Aw, 2014). The concept of liveability is simple: it evaluates which locations provide the best or the worst living conditions. Assessing liveability has a broad range of uses. The Economist Intelligence Unit's liveability rating quantifies the challenges that might be presented to an individual's lifestyle in any given location, and allows for direct comparison between locations. Melbourne remains the most liveable location of the 140 cities surveyed, followed by Vienna since the year of 2012. Vancouver was the most liveable city surveyed until 2011, today; it is on the third place. The 140 involved cities are evaluated by 30 qualitative and quantitative factors across five categories: stability; healthcare; culture and environment; education; and infrastructure (The Economist Intelligence Unit 2014) (Tab. 3).

Table 3 Economist Intelligence Unit - Global Liveability Ranking TOP 10 (2011-2015)

\begin{tabular}{|c|c|c|c|c|c|}
\hline & $\mathbf{2 0 1 1}$ & $\mathbf{2 0 1 2}$ & $\mathbf{2 0 1 3}$ & $\mathbf{2 0 1 4}$ & $\mathbf{2 0 1 5}$ \\
\hline $\mathbf{1}$ & Vancouver & Melbourne & Melbourne & Melbourne & Melbourne \\
\hline $\mathbf{2}$ & Melbourne & Vienna & Vienna & Vienna & Vienna \\
\hline $\mathbf{3}$ & Vienna & Vancouver & Vancouver & Vancouver & Vancouver \\
\hline $\mathbf{4}$ & Toronto & Toronto & Toronto & Toronto & Toronto \\
\hline $\mathbf{5}$ & Calgary & Calgary & Calgary & Adelaide & $\begin{array}{c}\text { Calgary, } \\
\text { Adelaide }\end{array}$ \\
\hline $\mathbf{6}$ & Helsinki & Adelaide & Adelaide & Calgary & - \\
\hline $\mathbf{7}$ & Sydney & Sydney & Sydney & Sydney & Sydney \\
\hline $\mathbf{8}$ & Perth, Adelaide & Helsinki & Helsinki & Helsinki & Perth \\
\hline $\mathbf{9}$ & - & Perth & Perth & Perth & Auckland \\
\hline $\mathbf{1 0}$ & Auckland & Auckland & Auckland & Auckland & Helsinki, Zurich \\
\hline
\end{tabular}

Source: Edited by author based on Global Sherpa, 2011; The Economist Intelligence Unit, 2012; Huffington Post, 2013; The Economist Intelligence Unit, 2014; economist.com, 2015

According to the other liveability research, the "Quality of Living Survey" released by global consultancy Mercer, Vienna is the most liveable city on the earth since 2009. Mercer performs this survey each year in 223 metropolises. Cities are evaluated across 39 metrics in 10 groups, including "political and social environment," "economic environment," "medical and health considerations," "schools and education," "consumer goods," and "housing" (Forbes, 2015) Overall, European cities dominate the top of the ranking along with major cities in Australia and New Zealand. Zurich, Auckland, and Munich are in second, third, and fourth place respectively. In fifth place, Vancouver is the highest-ranking city in North America and the region's only city in the top 10 (uk.mercer.com, 2015) (Tab. 4). 
Table 4 Mercer - Quality of Living Survey TOP 10 (2009-2015)

\begin{tabular}{|c|c|c|c|c|c|c|c|}
\hline & $\mathbf{2 0 0 9}$ & $\mathbf{2 0 1 0}$ & $\mathbf{2 0 1 1}$ & $\mathbf{2 0 1 2}$ & $\mathbf{2 0 1 3}$ & $\mathbf{2 0 1 4}$ & $\mathbf{2 0 1 5}$ \\
\hline $\mathbf{1}$ & Vienna & Vienna & Vienna & Vienna & Vienna & Vienna & Vienna \\
\hline $\mathbf{2}$ & Zurich & Zurich & Zurich & Zurich & Zurich & Zurich & Zurich \\
\hline $\mathbf{3}$ & Geneva & Geneva & Auckland & Auckland & Auckland & Auckland & Auckland \\
\hline $\mathbf{4}$ & $\begin{array}{c}\text { Vancouver } \\
\text { Auckland }\end{array}$ & $\begin{array}{c}\text { Vancouver } \\
\text { Auckland }\end{array}$ & Munich & Munich & Munich & Munich & Munich \\
\hline $\mathbf{5}$ & - & - & $\begin{array}{c}\text { Vancouver } \\
\text { Düsseldorf }\end{array}$ & Vancouver & Vancouver & Vancouver & Vancouver \\
\hline $\mathbf{6}$ & Dusseldorf & Dusseldorf & - & Dusseldorf & Dusseldorf & Dusseldorf & Dusseldorf \\
\hline $\mathbf{7}$ & Munich & $\begin{array}{c}\text { Frankfurt } \\
\text { Munich, }\end{array}$ & Frankfurt & Frankfurt & Frankfurt & Frankfurt & Frankfurt \\
\hline $\mathbf{8}$ & Frankfurt & - & Geneva & Geneva & Geneva & Geneva & Geneva \\
\hline $\mathbf{9}$ & Bern & Bern & $\begin{array}{c}\text { Copenhagen } \\
\text { Bern }\end{array}$ & Copenhagen & Copenhagen & Copenhagen & Copenhagen \\
\hline $\mathbf{1 0}$ & Sydney & Sydney & - & $\begin{array}{c}\text { Bern } \\
\text { Sydney }\end{array}$ & $\begin{array}{c}\text { Bern } \\
\text { Sydney }\end{array}$ & Sydney \\
\hline
\end{tabular}

Source: Edited by author based on Frankfurt.de, 2008; Livemint.com, 2009; Malaysia-Finance Blogspot, 2010; Mercer, 2014; Huffington Post, 2014, 2015, Mercer 2015

Some of the world's most liveable cities provide publicly accessible green spaces ${ }^{7}$ with physical amenities in the heart of their neighbourhoods. It should therefore come as no surprise that Vienna, which regularly ranks in the top positions for the world's most liveable cities, is one of the greenest cities of over a million inhabitants in the world. $51 \%$ of Vienna is classified as green space. For each of Vienna's 1,7 million inhabitants, there are 120 square meters of green space (Baharash Architecture, 2016).

Last examined index in this paper is the "City Prosperity Index". In the report entitled "State Of The World Cities 2012/2013", the United Nations Human Settlements Programme (UN-Habitat) has ranked 70 international cities for prosperity.

UN-Habitat has defined the prosperity as "a social construct that materializes in the realm of human actions. It builds deliberately and conscientiously on the objective conditions prevailing in a city at any time, wherever located and however large or small. It is a broader, wide-ranging notion that has to do with well-balanced, harmonious development in an environment of fairness and justice” (UN-Habitat, 2013:11).

The cities were evaluated by UN-Habitat in terms of productivity, infrastructure development, quality of life, social equality and environmental sustainability. The productivity index is measured through the city product, which is composed of the variables capital investment, formal/informal employment, inflation, trade, savings, export/import and household income/consumption. The infrastructure development index combines two subindices: one for infrastructure, and another for housing. The infrastructure sub-index includes

\footnotetext{
${ }^{7}$ Accessible green space is considered to be that which is located close to residents' homes, easy to walk to, physically accessible, safe to use, and provides well maintained facilities. [Definition by Public Health England]
} 
the connection to services, waste management, knowledge infrastructure, health infrastructure, transport and road infrastructure. The housing sub-index includes building materials and living space. The quality of life index is a combination of four sub-indices: education, health, safety/security, social capital and public space. The sub-index education includes literacy, primary, secondary and tertiary enrolment. The sub-index health includes life expectancy, under-five mortality rates, HIV/AIDS, morbidity and nutrition variables. The equity and social inclusion index combines statistical measures of inequality of income/consumption (Gini coefficient) and social and gender inequality of access to services and infrastructure. The environmental sustainability index is made of four sub-indices: air quality, CO2 emissions, energy and indoor pollution (UN-Habitat 2013). With excellent credentials in all fields evaluated, Vienna tops this list, outperforming metropolises such as Tokyo, London and Paris (wien.gv.at 2014). Large cities with high living standards such as Vienna did particularly well in the report thanks to their balanced societies. Good government and urban planning as well as appropriate laws and regulations enable cities such as these to offer a living environment which is exceptionally safe and secure. Other important factors taken into account were access to education and life expectancy. According to the study's authors if these preconditions met they will automatically be accompanied by a high degree of equity and equality (advantageaustria.org, 2012) (Fig. 6.).

UN-Habitat transformed the City Prosperity Index into a global initiative known as the City Prosperity Initiative. This initiative is both a metric and a policy dialogue, which offers cities the possibility to create indicators and baseline information. It also serves to define targets and goals that can support the formulation of evidence-based policies, including the definition of city-visions and long-term plans. UN-Habitat's City Prosperity Initiative (CPI) not only provides indices and measurements relevant to cities, it also enables city authorities to identify opportunities and potential areas of intervention for their cities to become more prosperous. Organized by UN-Habitat, the first Mayoral Conference on the City Prosperity Initiative was held in Vienna with over 100 participants in 2015 (UN-Habitat, 2015). 
Figure 6 City Prosperity Index and its components - UN-HABITAT (2012/2013) (TOP 10)

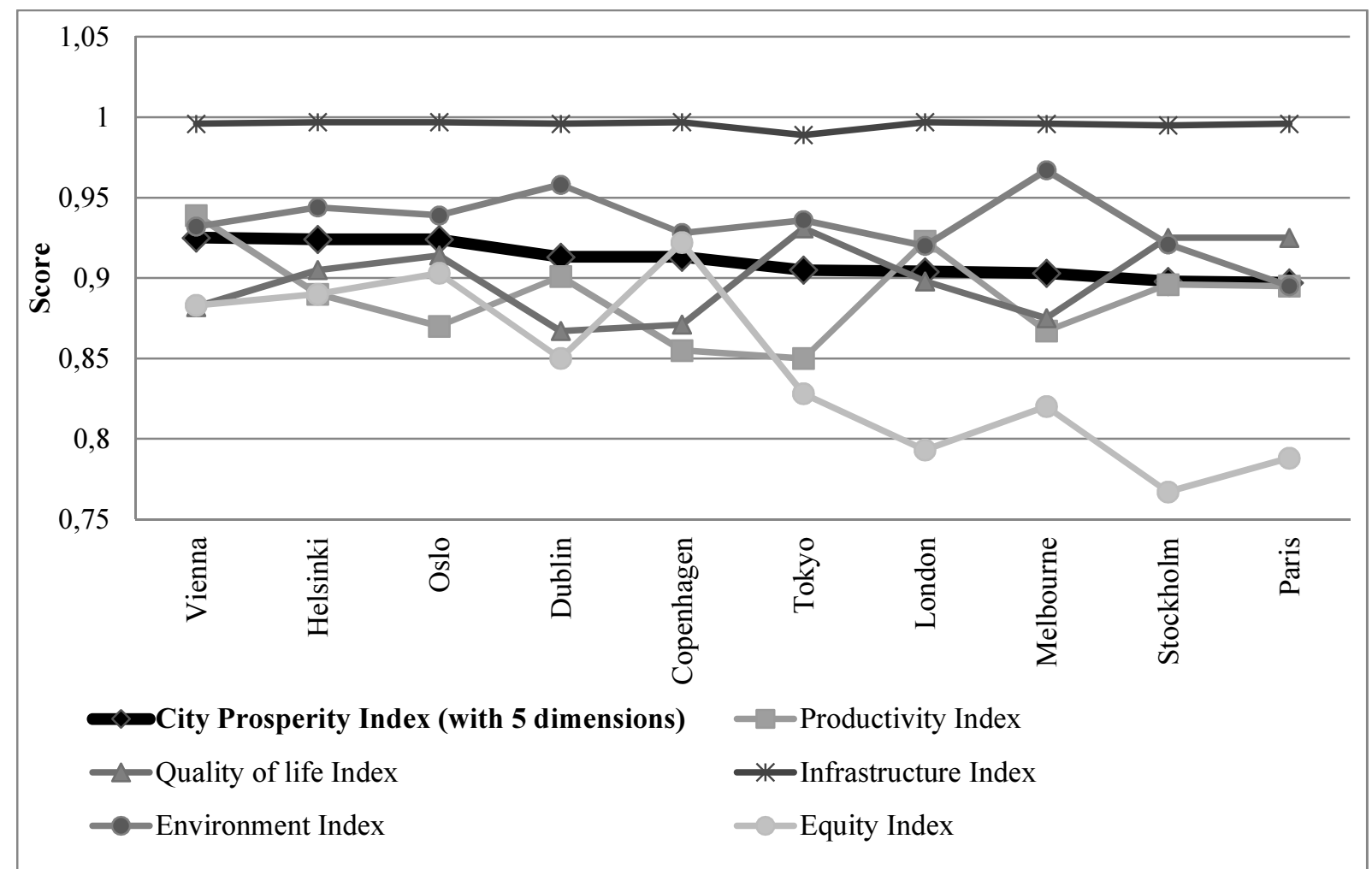

Source: Edited by author based on UN-HABITAT - State of the world's cities 2012/ 2013 - Prosperity of Cities

\section{CONCLUSION}

Based on the investigation, the several city rankings are able to highlight on strengths and weaknesses of a given city and can give a picture about the development path of cities if they are published year by year. To answer the main research question (can we consider Vienna as a real world or global city, and if so, what kind of economic, social, environmental or other factors are able to strengthen its position at global scale?) we can say, that the Austrian capital is a world city, because it is a member of the world city hierarchy (Friedmann, 1986), moreover, the city is included into the most world and global city rankings. In the case of Vienna, it can be clearly seen, that the main priorities of the city are related to the needs of local inhabitants and their liveable, sustainable environment. The culture and tourism also play a dominant role in its "Smart City" approach. Based on the results of global city rankings, the Austrian capital can be considered globally underperforming in dimensions of business and financial sector (compared to the liveability, environment and culture) therefore, its global position is much weaker in this point of view. So, the city may have two possibilities for the future: it follows the begun development path and pay more attention on the environment than on economic benefits, or the management of the city tries to strengthen 
the weaker factors, such as the business and financial sectors. This type of decision may be important not only for the policymakers of Vienna, but other cities need to face to it, as well.

\section{Acknowledgements}

Research for this publication has been supported by National Research, Development and Innovation Office - NKFIH grant \#NN 114468 (Change and Continuity in Hungarian Spatial Imaginaries: Nationality, Territoriality, Development and the Politics of Borders).

\section{REFERENCES}

Advantageaustria.org, (2012). Vienna: The world's most prosperous city. http://www.advantageaustria.org/dk/oesterreich-in-denmark/news/local/20121106Wien---Stadt-mit-dem-hoechsten-Wohlstand-.en.html_[2015.10.14.]

Albino, V., Berardi, U., \& Dangelico, R.M. (2015). Smart Cities: Definitions, Dimensions, Performance, and Initiatives. Journal of Urban Technology, Vol. 22, No. 1, 3-21.

A.T. Kearney (2015). Global Cities Index. https://www.atkearney.com/researchstudies/global-cities-index/2015 [2016.02.07.]

Baharash Architecture (2016) Liveable cities: how much green space does your city have? http://www.baharash.com/liveable-cities-how-much-green-space-does-your-city-have/ [2016.02.07.]

Beaverstock J.V., Smith, R.G., \& Taylor, P.J. (1999). A Roster of World Cities. In: Cities, 16 (6), 445-458.

Begg, I. (1999). Cities and Competitiveness, Urban Studies, Vol. 36, 5-6, 795-810.

Bourdeau-Lepage, L. (2007) Advanced services and city globalization on the Eastern fringe of Europe. Belgeo (1), 133-146.

Castells, M. (1989). The Informational City. Information, Technology, Economic Restructuring and the Urban-Regional Process. Oxford and Cambridge: Blackwell Publishers.

Cohen, B. (2012). The Top 10 Smart Cities On The Planet. http://www.fastcoexist.com/1679127/the-top-10-smart-cities-on-the-planet [2016.02.07.]

Economist.com (2015). The world's most 'liveable' cities http://www.economist.com/blogs/graphicdetail/2015/08/daily-chart-5 [2016.01.05.]

Foley, P. (2013). Defining Smart Cities https://ec.europa.eu/digital-agenda/en/content/ defining-smart-cities [2016.01.16.]

Forbes (2015). Vienna Tops 2015 List Of The Most Liveable Cities On Earth. http://www.forbes.com/sites/kathryndill/2015/03/05/vienna-tops-2015-list-of-the-mostlivable-cities-on-earth/_[2016.02.06.]

Frankfurt.de (2008). Quality of Living global city rankings - Mercer survey https://www.frankfurt.de/sixcms/media.php/738/MercersPressRanking2008.pdf [2016.01.08.] Friedman, J., \& Goetz, W. (1982). World City Formation: An Agenda for Research and Action, International Journal of Urban and Regional Research. Vol. 6, No. 2, p. 319.

Friedmann, J. (1986). The World City Hypothesis. Development and Change, Vol. 17, No.1, 69-83.

Geddes, P. (1915). Cities in evolution: an introduction to the town planning movement and to the study of civics. Williams, London. p. 446. 
Giap, T.K., Thye, W.W., \& Aw, G. (2014). A new approach to measuring the liveability of cities: the Global Liveable Cities Index, World Review of Science, Technology and Sustainable Development, Vol. 11, No. 2, 176-196.

Giffinger, R., \& Haindl, G. (2009) Smart cities ranking: An effective instrument for the positioning of cities? http://upcommons.upc.edu/bitstream/handle/2099/11933/05_PROCEEDINGS_M5_01_ 0014.pdf [2016.02.07.]

Global Sherpa (2011). World Cities: Best Quality of Living and Liveability http://www.globalsherpa.org/most-liveable-cities-quality-of-living-survey [2015.12.13.]

Grosfoguel, R. (1995). Global logics in the Carribean city system: the case of Miami. In: Knox P L (ed.), World cities in a world system. Cambrige, pp. 156-170.

Hall, P. (1966). The World Cities. New York: McGraw-Hill, World University Library, p. 7.

Hardi, T. (2010). Cities, Regions and Transborder Mobility Along and Across the Border. Discussion Papers No. 82. Centre for Regional Studies of the Hungarian Academy of Sciences. Pécs

Huffington Post (2013). The Most Liveable Cities of 2013 http://www.huffingtonpost.com/2013/08/28/worlds-most-liveable-cities2013_n_3831701.html [2015.10.14.]

Huffington Post (2014). Mercer Quality Of Living Survey Ranks Top Cities In The World To Live (Photos) http://www.huffingtonpost.ca/2014/02/19/mercer-quality-of-livingsurvey_n_4816226.html [2015.10.14.]

Huffington Post (2015). This 2015 Quality Of Life Survey Just Confirms What Canadians Know. http://www.huffingtonpost.ca/2015/03/04/2015-quality-of-life_n_6800320.html [2016.02.07.]

IESE Business School University of Navarra (2015). Cities in Motion Index http://www.iese.edu/research/pdfs/ST-0366-E.pdf [2016.01.15.]

Institute for Urban Strategies The Mori Memorial Foundation (2015). Global Power City Index 2015. http://www.mori-m-foundation.or.jp/english/ius2/gpci2/ [2016.01.15.]

Leff, S., \& Petersen, B. (2015). Beyond the Scorecard: Understanding Global City Rankings. http://www.thechicagocouncil.org/sites/default/files/BeyondtheScorecardReport.pdf [2016.02.07.]

Lengyel, I. (2009). Bottom-up Regional Economic Development: Competition, Competitiveness and Clusters. In: Bajmócy, Z. - Lengyel, I. (eds): Regional Competitiveness, Innovation and Environment. JATEPress, Szeged, 13-38.

Livemint.com (2009). Mercer Quality of Living Survey - Worldwide Rankings, 2009 http://www.livemint.com/r/LiveMint/Period1/oldpdf/b41a627b-1b1a-43a5-93c8d38996599658.pdf [2015.10.12.]

Maceda, C. (2015.) Revealed: World's most powerful cities. Latest research ranks 40 mega cities according to their power to attract businesses, human capital. Gulf News Economy. http://gulfnews.com/business/economy/revealed-world-s-most-powerfulcities-1.1600825_[2016.01.17.]

Malaysia-Finance Blogspot (2010). Quality of Living worldwide city rankings 2010 - Mercer survey http://malaysiafinance.blogspot.hu/2010/05/quality-of-living-worldwidecity.html [2015.10.12.]

Mercer (2014). Quality of living worldwide city rankings - TOP 5 Cities http://www.mercer.com/newsroom/2014-quality-of-living-survey.html [2015.10.14.]

Mercer (2015). Quality of living worldwide city rankings - TOP 5 Cities https://www.imercer.com/content/quality-of-living.aspx [2016.01.15.]

Musil, R. (2009). Global capital control and city hierarchies: an attempt to reposition Vienna in a world city network. Cities, 26 (5), 255-265 
Parnreiter, Chr (2002). Mexico: The making of a global city. In: Sassen, S (ed.), Global Networks, linked Cities. London, New York, pp. 215-238.

Pearce, T., \& Wyly, E. (2006). Globalization and World Cities Geography 350, Introduction to Urban Geography. http://ibis.geog.ubc.ca/ ewyly/g350/global_[2015.10.17.]

Rossi, E. C., Beaverstock, J. V., Taylor, P. J. (2007). Transaction Links through Cities: ' Decision Cities ' and ' Service Cities ' in Outsourcing by Leading Brazilian Firms. Geoforum 38(4), 628-642

Rubia, J. (2015) Global Power City Index 2015 Report Unveils World's Most Powerful Cities https://www.linkedin.com/pulse/global-power-city-index-2015-report-unveils-worldsmost-de-la-rubia_[2016.01.17.]

Sassen, S. (1991). The Global City: New York, London, Tokyo. Princeton.

Sassen, S. (1994). Cities in a World Economy, Thousand Oaks, Calif.: Pine Forge Press.

Smart City Wien Framework Strategy (2014). https://smartcity.wien.gv.at/site/files/2014/09/SmartCityWien_FrameworkStrategy_engl ish_doublepage.pdf_[2016.01.17.]

The Economist Intelligence Unit (2012). A Summary of the Liveability Ranking and Overview $\quad$ August 2012. http://www.2013wmc.org/wpcontent/uploads/2012/08/Melbourne-Most-Liveable-City-August-2012.pdf [2016.01.14.]

The Economist Intelligence Unit (2014). A Summary of the Liveability Ranking and Overview August 2014. http://pages.eiu.com/rs/eiu2/images/Liveability_rankings_2014.pdf [2016.01.14.]

2thinknow Global Innovation Agency (2014). Innovation Cities Program $\mathrm{http} / /$ www.innovation-cities.com/reference/index/ [2016.01.14.]

2thinknow Global Innovation Agency (2014). Cities: 3 factors. http://www.citybenchmarkingdata.com/cities-3-factors [2016.01.14.]

2thinknow Global Innovation Agency (2016) Innovation Cities Index 2015 Global $\mathrm{http} / / \mathrm{www}$.innovation-cities.com/innovation-cities-index-2015-global/9609 [2016.02.07.]

Uk.mercer.com (2015). Vienna tops latest quality of living rankings. http://www.uk.mercer.com/newsroom/2015-quality-of-living-survey.html_[2016.02.07.]

UN-Habitat (2013). State of the World Prosperity, Prosperity of Cities. 2012/2013. p 207.

UN-Habitat (2015). Vienna hosts first mayoral conference on City Prosperity Initiative http://unhabitat.org/vienna-hosts-first-mayoral-conference-on-city-prosperity-initiative/ [2015.12.01.]

United Nations Department of Economic and Social Affairs (2014) World's population increasingly urban with more than half living in urban areas https://www.un.org/development/desa/en/news/population/world-urbanizationprospects.html_[2016.02.01.]

Wien.gv.at (2014). Vienna's performance in international competition https://www.wien.gv.at/english/politics/international/competition/rankings.html [2016.02.07.] 